$\xi=$

\title{
Solar auto irrigation control (SAIC) using resistivity measurement at multiple points
}

\author{
V. K. Singh ${ }^{1}$ *, Anurag Saxena ${ }^{1}$, Ritik Kumar Gupta ${ }^{1}$, Nidhi Verma ${ }^{1}$, Taruna Kushwaha ${ }^{1}$, Gyoo-Soo Chae ${ }^{2}$, \\ Ashis Sharma ${ }^{3}$, Akash Kumar Bhoi ${ }^{4}$ \\ ${ }^{1}$ Dept. of Electrical Engineering, SR Group of Institutions Jhansi, U.P. India \\ ${ }^{2}$ Sikkim Manipal Institute of Technology (SMIT), Sikkim Manipal University, India \\ ${ }^{3}$ Division of Information and Communication, Baekseok University, Cheonan, South Korea \\ ${ }^{4}$ Department of Electrical \& Electronics Engineering, Sikkim Manipal Institute of Technology (SMIT), Sikkim Manipal University, India \\ *Corresponding author E-mail: singhvinod34@gmail.com
}

\begin{abstract}
In this article, a special type of microcontroller named as Arduino Nano 3.0 (ATMega 328) is used for the operation of an automatic irriga-tion system which is powered by solar energy. Here, the resistivity of soil is measured with the use of electrode (resistivity sensor). Through this type of irrigation system the farmer can use automatic 'ON' and 'OFF' system for water pump for irrigation. A complete hardware implementation is also presented in this paper.
\end{abstract}

Keywords: Automatic Irrigation; Microcontroller Atmel Atmega328; Proteus-8.1; Electrode; Renewable Energy; ETC

\section{Introduction}

In India, mostly agriculture irrigation depends on rain or artificial resources like canal and well. Natural resource of irrigation is raining, but the period of rain is too small, so totally agriculture depends on artificial resource. Water pumps are established for irrigation, but in India electricity supply is not abundance, so by harnessing solar energy electricity consumption reduces [1-2].

Farmers usually visit the site for observing water level and weather conditions to control water pump manually. This leads to waste of electricity and water due to unplanned manually switching of the water pump. Thus, this brings the need to move to automation of irrigation system [3-5].

Automatic irrigation system is designed for proper level of water for growing up the plants in all seasons by using solar energy, which is cheap and abundant on earth. In the absence of farmers, proper functioning of water pump ON/OFF is held automatically and maintains the water requirement in the field [6].

Farmers get notification when the water pump is ON/OFF by GSM mode. With the development of automatic irrigation technology, water and electricity conservation along with automation of irrigation system is achieved [7-8].

\section{Microcontroller}

In this we have used Arduino Nano, which has microcontroller ATmega328 as a main board. The size of Arduino Nano is a petite, inclusive, and PCB-friendly board based on the ATmega328. It has more or less the same functionality of the Arduino Duemilanove, but in a different package. It lacks only a DC power jack, and works with a Mini-B USB cable instead of a standard one. The design of Arduino Nano was developed by Gravitech. At pin 30, 6-20 V unregulated (not pure DC) external power supply is applied at pin 27 around 5V regulated power supply is applied. Pin diagram of Arduino Nano is shown in figure 1. Table 1 shows the various specification of the Microcontroller.

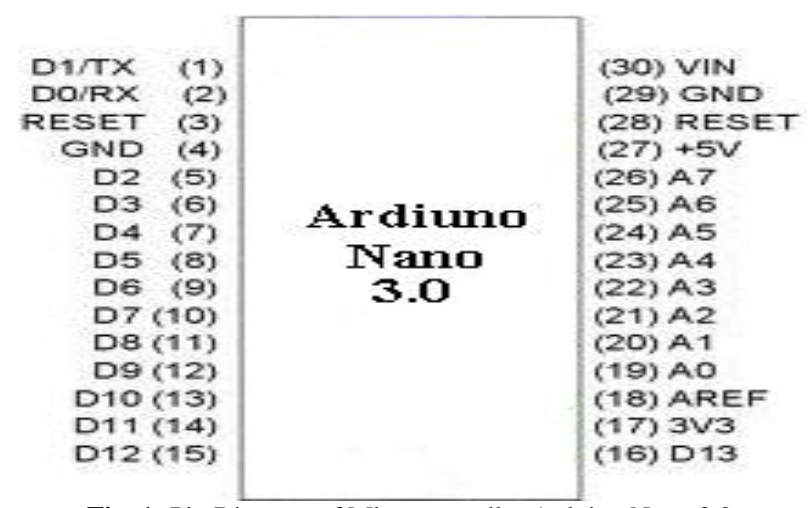

Fig. 1: Pin Diagram of Microcontroller Arduino Nano 3.0.

Table 1: Specification of Arduino Nano 3.0

\begin{tabular}{ll}
\hline Arduino Nano 3.0 & Atmel ATmega328 \\
\hline Working Voltage & $5 \mathrm{~V}$ \\
Input Voltage & $7-12 \mathrm{~V}$ \\
Analog Input Pins & 8 \\
DC Current per I/O Pin & $40 \mathrm{milli}-\mathrm{Amp}$ \\
Dimensions & $0.73 \mathrm{~mm}$ x $1.70 \mathrm{~mm}$ \\
Clock Speed & $16 \mathrm{MHz}$ \\
EEPROM & $1 \mathrm{~KB}$ \\
\hline
\end{tabular}

\section{Working principle}

Figure 2 shows the block diagram of solar automatic irrigation in which a solar panel is used with solar tracker to improve the efficiency of the system and maintain the voltage throughout the day. 
We have used servo motor and LDR to make solar tracker. The battery is charged up to $12 \mathrm{~V}$. The voltage is given to microcontroller which controls the whole function. The function provided by Arduino are taking input from moisture sensor device, controlling pump ON/OFF as per the moisture in the field through electromagnetic relay. The pump is $\mathrm{ON}$ when any of the two sensors are dry and OFF when all the three sensors are wet. This whole process is shown on the LCD provided. In addition to this, farmer present at remote area are also get cell notification through device called SIM 900 in a mobile. Thus irrigation of agriculture field can be automatically controlled without wastage of water and absence of farmers.

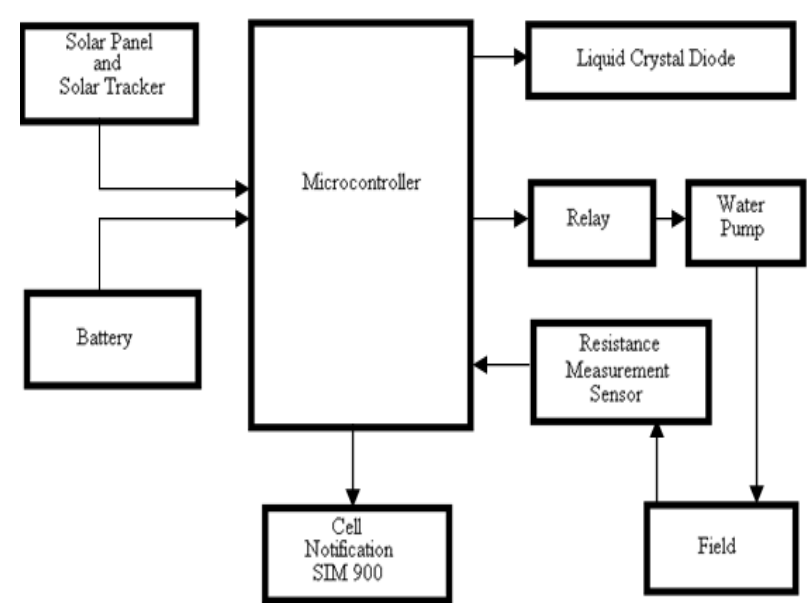

Fig. 2: Block Diagram of Solar Automatic Irrigation Using Arduino Nano.

\section{Result and discussion}

This project thus helps to sense the moisture level in the field by measuring the resistance between the electrode points. When any two of the sensor resistance is high the microcontroller gives signal to relay \& thus pump is switch ON automatically till all the 3 electrodes sensors resistance becomes low. Thus the project shown below is very useful and easy to solve the problem of irrigation in ground. After checking the soil, if it is dry then farmer get the message in the mobile for switch ON the pump and if it is wet then also farmer get message for switch OFF the pump. Fig 3 shows the hardware of Solar Auto Irrigation Control (SAIC) system.

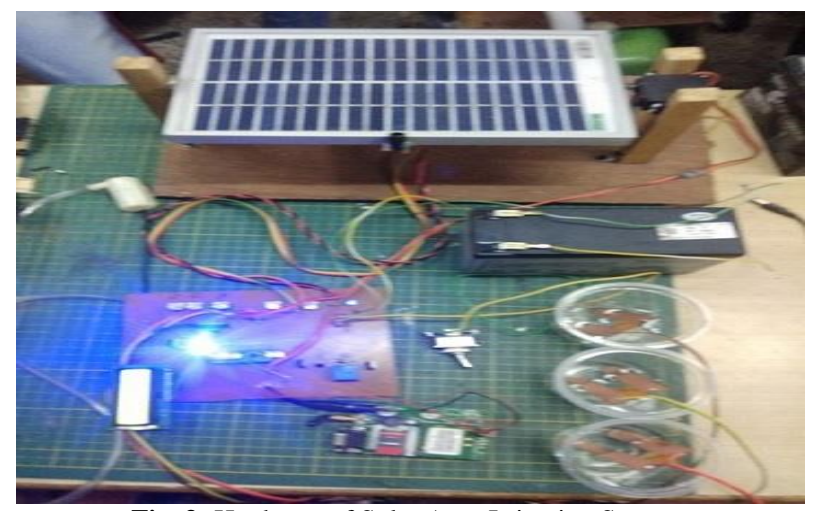

Fig. 3: Hardware of Solar Auto Irrigation System.

\section{Conclusion}

The Arduino Nano microcontroller is an important device for precise dampness control in irrigation field. This project helps to remove error generated by humans in adjusting dampness level to make the most of net profits by saving in water. The key features of this project are use of solar energy with solar tracker closed loop automatic irrigation system and water usage monitoring. This irrigation system allows enlargement in places with water shortage thereby humanizing sustainability. We have used electrode made up of copper PCB, which is cheaper than a soil moisture sensor. To solve social, economic and environmental and society problem for one's country which it will lead to development, this type of solar system is very helpful for these purposes.

\section{References}

[1] S. Harishankar, R. Sathish Kumar, Sudharsan K. P, U. Vignesh, T. Viveknath, "Solar Powered Smart Irrigation System", Advance in Electronics and Electrical Engineering, Vol. 4, No.4 (2014), pp: 341-346.

[2] K. Prathyusha, M. Chaitanya Suman, "Design of Embedded Systems for the Automation of Drip Irrigation", International Journal of Application or Innovation in Engineering \& Management (IJAIEM), Vol. 1, Issue 2, (2012), and pp: 254-258.

[3] K. K. Tse, M. T. Ho, H. S. H. Chung, S. Y. Hui , "A novel maximum power point tracker for PV panels using switching frequency modulation", IEEE Trans. Power Electron., Vol. 17, Issue 6, (2006), pp: 980-989.

[4] Prakash Persada, Nadine Sangsterb, Edward Cumberbatch, Aneil Ramkhalaw and Aatma Maharajh, "Investigating the Feasibility of Solar Powered Irrigation for Food Crop Production" A Caroni Case, The Journal of the Association of Professional Engineers of Trinidad and Tobago, Vol.40, No.2, (2011), pp: 61-65.

[5] J. Alvarez Mozos, J. Casali, M. Gonzalez-Audicana, N. E. C. Verhoest, "Assessment of the operational applicability of RADARSAT-1 data for surface soil moisture estimation", IEEE Trans. Geosci. Remote Sens., Vol. 44, No. 4, (2006), pp: 913-924.

[6] N. Baghdadi, N. Holah, M. Zribi, "Soil moisture estimation using multi-incidence and multi-polarization ASAR SAR data", Int. J. Remote Sens., Vol. 27, No. 10, (2006), pp: 1907-1920.

[7] Mahir Dursun and Semih Ozden, "A wireless application of drip irrigation automation supported by soil moisture sensors", Proceedings of the Scientific Research and Essays Vol. 6(7), (2011), pp: 1573-1582.

[8] F. Mattia, G. Satalino, V. R. N. Pauwels, A. Loew, "Soil moisture retrieval through a merging of multi-temporal L-band SAR data and hydrologic modeling", Hydrol Earth Syst. Sci., Vol. 13, No. 3, (2009), pp: 343-356. 